\title{
Perception and the Mood of Change
}

\author{
by HENRYK HOLLENDER \& EWA KOBIERSKA-MACIUSZKO
}

It was already four years ago when one of us had a chance to present the design of the new building of the Warsaw University Library on the LIBER seminar in Paris. Nearly four months ago first patrons entered the building. Four years is not much when compared to the 195 years of Warsaw University (and its Library!), but considering us librarians those fours years brought about a real revolution.

To elaborate on this, we have to go back to the requirements we compiled for the contest organized by the Society of Architects in May 1993.

We wanted a new edifice, as going to serve as a public place, to combine the aspect of space and the aspect of function, or organization, or ,action in the effect to...". The library is one more organized public space, and the very term „public" is quite dynamic in this case, from ancient times when libraries served small circles to the modern times when libraries in a sense manage knowledge in democratic societies. The library's layout is the reflection of the library's social function. Our old edifice was a $19^{\text {th }}$ century tower bookstore with the public function wrapped around it. Following the writings of Leopoldo della Santa, the front part of the building consisted of the reading rooms and offices, separated with a firewall from the back two third of the structure, where a store of seven levels was built, in which stacks were the actual construction and ceilings/floors were made of pig iron grate.

In that interior, in May 1993 we had to decide whether we would observe the respectable tradition of collection management, or customers' habits and our own workflow, or whether we will try another paradigm, which we watched and liked in American and European libraries. Yes, we were lured by the vision of the open-stacks library, and we surrendered. It is not difficult to explain why. First, we felt that open shelf-arrangement would be more userfriendly and will give a new, pluralistic flavour to the procedure of studying. Then we thought that it would better support interdisciplinary selection of courses by students and encourage them to locate supplementary (as opposed 
to strictly assigned) reading materials, thus promoting intellectual inquiry and making our inadequate resources better used. Still, the decision was dramatic, as six years ago only small public libraries sported open stacks, and in the academic world the whole scheme, while in a sense known and accepted, was not supposed to happen just here. We were also afraid that we would not be able to bind all the open stacks volumes (very correctly so), and that they would physically disintegrate in a very rapid manner. We are now trying to face this problem.

The requirements only mentioned the area of the mixed function of the store and the reading room. Then architects took over, creating a vision of the library for both "town" and ,gown” types of audiences, which could equally well serve a beginner and an experienced user of the old building and the old institution. Then, again, our work was necessary to complete the technical design of the Library, and to depart from the general ,open stacks” concept to today's combination of eight broad areas with their focal points and their subject specialists present to assist the user. It is necessary to stress here that our user is left to choose her or his preference on how to call and define the place and how to behave in it. She may call it a reading room with an extensive reference collection, or she may admit that it is an unstructured environment in which almost any adventure can happen.

The project was subject to tremendous social pressure. Today over 1,000 people walk through the arcade, climb the Propylaeum and depart in all the directions from the catalogue hall. It could have easily not ended like that. Let's supplement some of this morning's information by President Robert Rzesos.

In the times of the People's Republic of Poland the Warsaw University, which gave the country so many dissidents, and maintained so naturally links to the international intellectual scene, was not to be rewarded with a major investment. It applied not only to the library. When the regime fell in 1989, the nation was swept by a public discusssion on how to reintegrate and strenghthen this school. The discussants included one more topic: how to use the former communist party's headquarters. The impressive structure near the National Museum was robust enough to be passed to the University, but it would not immediately make a library, and would not at all make a modern library for 2.3 million items. Then the first non-communist government headed by Mr Tadeusz Mazowiecki established a state-controlled company to operate the building, to let its offices, and to generate income which would finance the project of building the Warsaw University Library. 
And this is how the cohabitation between the Library and the Banking Center (whose money were used by the Warsaw University Foundation) started. The Banking Center was aware at that time that the maintenance of the Library would be a very serious burden to the University, whose budget is shaped by the Ministry of Education on the basis of a formula, composed of the number of students enrolled, the number of employees holding at least a doctoral degree, and on the last-year's funding. The range and quality of educational services is beyond the formula funding; also the Ministry has not collected data on performance of particular libraries. Having a state-of-the-art library does not help to have its bills payed; the effort to improve your services may only informally be rewarded by better funding. The other thing the Center was aware of was that the necessary money would not be raised until long after the project is completed. The investment required crediting; the credit is expected to be paid back by 2004, so it has to be admitted that it was wise for the Center to leave some of the rooms in the Library for rent. Most of these rooms are concentrated in the front part of the building, or the Croissant, separated from the actual library by an arcade with a skylight, or The Lane.

To be sure, there is some bitterness on the side of librarians that the project would not happen without turning the part of the Library into one more „plaza”, an element so distinctive to Warsaw's new architecture in the nineties as needed by the new financial establishment of the country's capital. Some difficulties have emerged in getting rid of the offices temporarily located in the „library” part of the building. And it is a pity we no longer have that high-tech conference centre designed originally in the first underground level, now converted into a bowling club in which we'll be dining tonight. Our personal hope is that the University will claim the conference centre after 2004, and that the Library won't really need the Croissant - instead, a school of information studies and other teaching units could be assigned space there. The mood of change has to remain with us for some decades yet.

Of the genuine library part, the following components of the Library should be listed:

- Level Zero, or Ground, where entrances are organized (with only one way for the user to get into the premises), and which is dominated by the compact storage but also includes a preservation and conservation as well as acquistions rooms and labs;

- Level One, dominated by the reference and circulation services, with the big catalogue hall in the atrium, open stacks areas, and offices in the southern part of the building; 
- Level Two, dominated by open stacks, the traditional reading room, current periodicals and library administration;

- Level Three, dominated by the special collections, but with a big exhibition hall accessible for special collections non-users. On this level we will also gather almost all of our $19^{\text {th }}$ century collections, so rich in Russian and other foreign-language books and scholarly journals. They will become one more special collections unit, but with some form of open access to research workers and graduate students, with the early $19^{\text {th }}$ century classification remade as a basis for shelf arrangement, but also with some collections grouped according to provenance on genre criterion. With $19^{\text {th }}$ century materials being foolishly perceived in Poland as „contemporary”, we believe we are about to add a new value to the issue of preservation and access, and we know many of our professors just cannot wait until the "19 $19^{\text {th }}$ Century Room” opens. Of course, those materials are now regularly fetched to the reading room.

As we see it now, and with the most of special collections still not moved into the edifice, the most intriguing element here next to the open stacks is the concentration of so many of the transactions in the catalogue hall. You cannot just call to the library to use the catalogue, which was the regular practice in the old building; you have to get yourself a library card at the circulation desk, without the right to penetrate into the open stacks. With the card in your hands, however, the interior is all yours. This new practice is a surprise to many, who don't understand that the catalogue, with the progress of retrospective conversion, requires less and less physical presence of the user on the library premises. The same people who demand the immediate access, may go lost just after the entrance. Many tend not to study the visual information (which is incomplete anyway), refuse to read our brochures and fliers, and insist on personalized guidance of a staff member. One user even refused to pick up any open stacks items, and - encouraged to do so explained that he would not because „there are to many security people around". Others, however, got quickly accustomed to the open stacks system, and use it in inventive and relaxed ways, which is exactly what we wanted.

Nevertheless, there is a lot of crossing of routes in the catalog hall, and from time to time this forum (or agora, as Marek Budzynski put it) becomes a little chaotic and noisy. No doubt it will calm down when the new catalogue cabinets have arrived, but we also welcome an idea of adding a new kiosk at the entrance, which would handle the basic information and registration transactions, which would serve as a book drop, and which would eventually lower the number of people who enter the library without a need and intention to study. 
Also, the agora seen from the galleries is a very vivid public place, and some students are especially fond of occupying the tables which overlook it. They kick of their shoes, spread their materials, and watch the scene of the atrium while reading, taking notes, talking to a friend, receiving a phone call, or even having a sip of a soft drink from a bottle (which is basically illegal but we are unable to control it). We are happy that no particular discipline is imposed on users, because they are telling us that in the new building they generally do study more, as the classified shelf arrangement makes them find items they would not locate if left only with the catalogue. Also, we are happy that the Library is able to assume the role of the social hub of the University. One may recall here brilliant remarks of essayist Walter Benjamin, who once listed the nineteenth century institutions which gave one the chance ,to see and be seen" (with theatre coming as the obvoius number one among them). There was no library on his list, and indeed tripartite buildings would not qualify. It is ironic - and pleasant - that at the very end of the twentieth century we may point to a library as a place in which you do observe and are observed, and enjoy it equally as a dilligent reader, an Internet user, or someone who is just about to socialize.

Despite the hardships with equipping the building - which Robert Rzesos pointed to very mildly when referring to the contribution of the Ministry of Education, which arrived late - most of the opinion we are getting from the users is enthusiastic. Still, it is not like this that many contemplate the building. Subtle spatial distinctions or symbols described by Professor Marek Budzynski remain unnoticed by most; and many fail to follow the prescribed procedure of locating the open stacks items using the Library of Congress Classification, satisfying themselves with their intuition or just giving up when random walking the aisles brings no ,hits”. New spaces do not look the way we wanted because of the missing furniture, or equipment, or signage, and not all the routines are already under contol (hence the queues at the circulation desks, something we solemnly declared that would not happen in the new building). Generally, the staff were more susceptible to the "future shock” of moving than the clients, and we are only in the beginning of changing our technical routines, to use the newly designed spatial connections to their fullest potential, especially in processing of items.

Also, there is some positive impact of the new library on our staff. They are moved by working for such a famous institution, and touched by the splendour of the building. They take pride in arranging their offices, even if some alleged improvements are unacceptable for the architect. There is more team spirit, more identification with the organization as a whole, more formal and informal contacts between staff of various departments. We are also hoping that the staff will prove more open to workflow change; we believe 
that this small group we employed will be free from the obvious burden of old, not necessarily good habits.

The Library is there; it will serve the University and the general public, and it has to be paid for. The Warsaw University Foundation, fed by the Banking Center, handles basic utilities, and generates income - not only by space rental, but also by organizing events in the Lane and at the exhibition hall on the Ground Level. The Foundation also outsources the cleaning of the public entrance area, and all of the levels one and two. We find this service quite efficient. And the Foundation uses a security team to protect the entrances to the building and the parking lot, and the equipment as well as books in the public areas of the Library.

As for the budget the director is directly responsible for, the Library is going to spend nearly 8 million zloty this year, which is roughly an equivalent to some 2 million euro. As much as nearly 90 percent of this will be taken by wages. The remaining money will be divided like this:

- 692,000 - current expenditure, including collection building, but excluding journal subscription, which is covered by a separate grant;

- 60,000 - utilities not covered by the Warsaw University Foundation, like rubbish removal, lift maintenance, telephones etc.

Of the nearly 700,000 „current expenditure” money, we are hoping to receive a special grant from the university of at least 120,000 to meet the cost of equipping the new building. It is a very sensitive issue: basically we have received or we will receive all the furniture and equipment which was in the detailed design. But we did have to invest beyond it. We had to buy elements of the visual information, because - while being included in the design - it only partly arrived on time. And the other utensils were just impossible to include, so it is normal that the shopping list for the Ministry of Education had to leave substantial gaps. For instance, we needed mobile phones for the management of moving and also for easier contact with the library directors, we wanted stretchers in case of emergency, we wanted bulletin boards and lots of office supplies. Last but not least, we want our cleaning staff to use the same professional equipment which is used by the company which cleans the offices and the open stacks areas. On the top of that we are going to hire thirty more people - a very modest request in a building five times larger than our previous facilities altogether, with new reference services etc. And those people are also entitled to some new supplies. 
Thus you can see possessing a new library is not only a pleasure; it is also the cost. We believe it is also - and first of all - a benefit, but we admit that any calculation in this field is complex. The change we caused by wanting the new building, be designing it, by organizing it, and by running it, may be just a beginning of the domino-effect to extend on the whole of the University, and it is now up to the University where it will take it. But it has to be stressed that the Warsaw University is not scared of this case. New buildings are being erected or planned, and the school still has a chance to become one of the biggest and most reputable tertiary institutions of tomorrows Europe.

Henryk Hollender

Ewa Kobierska-Maciuszko

c/o University Library Warsaw

ul. Dobra 56/66

00-312 Warsaw, Poland

ewamac@plearn.edu.pl 